\title{
Ultrastructure of the Adhesion of Bacteria to the Epithelial Cell Membrane of Three-Day Postnatal Rat Tongue Mucosa: A Transmission and High- Resolution Scanning Electron Microscopic Study
}

\author{
Ii-sei WATANABE ${ }^{1}$ \\ Koichi OGAWA ${ }^{2}$ \\ Marcelo Cavenaghi Pereira da SILVA ${ }^{3}$ \\ Aracy Akiko MOTOYAMA ${ }^{1}$ \\ Eduardo Shigueaki KADO ${ }^{1}$ \\ Ruberval Armando LOPES ${ }^{4}$

\begin{abstract}
${ }^{2}$ Department of Anatomy, School of Medicine, Fukuoka University, Fukuoka, Japan
${ }^{3}$ Department of Morphology, Federal University of São Paulo, São Paulo, SP, Brazil

${ }^{4}$ Department of Morphology and Stomatology, School of Dentistry of Ribeirão Preto,

University of São Paulo, Ribeirão Preto, SP, Brazil
\end{abstract} \\ ${ }^{1}$ Department of Anatomy, Institute of Biomedical Sciences, University of São Paulo, São Paulo, SP, Brazil
}

\begin{abstract}
Togue mucosa surface of 3-day postnatal rats was examined under transmission electron microscopy (TEM) and high-resolution scanning electron microscopy (HRSEM). For HRSEM analysis, the specimens were fixed in the same solution for $24 \mathrm{~h}$, postfixed in $2 \%$ osmiun tetroxide, critical-point dried and coated with platinum-palladium. For TEM analysis, the specimens were fixed using modified Karnovsky solution and embedded in Spurr resin. The results revealed the presence of numerous microplicae in the membrane surface of keratinized epithelial cells to which groups of bacteria were attached. These bacteria were staphylococcus and coccus organized either in rows or at random, which were visualized in three-dimensional HRSEM images. At high magnification, the TEM images revealed the adhesion of bacteria to the cell membrane through numerous filamentous structures comprising the glycocalyx. The fine fibrillar structures rising from each bacterium and from cell membrane were clearly seen. These characteristics on bacteria structure may be used for future control or prevention of bacterial diseases and for installation of the oral native flora.
\end{abstract}

Key Words: epithelial cell, rat tongue, transmission electron microscopy, high-resolution scanning electron microscopy, bacteria.

\section{INTRODUCTION}

The oral cavity is one of the regular sites for bacterial adhesion, even before tooth eruption when the number of sites for colonization increases significantly. In rats, incisors erupt on the 6th or 7th postnatal day and, after that, the teeth and periodontal sulci are the preferred sites for bacterial colonization causing periodontal diseases and caries in several species.

Before tooth eruption, the mucosal surfaces are the only available areas for colonization and the epithelial cells of oral mucosa have been reported by several authors (1-4) using scanning electron microscopy (SEM) and transmission electron microscopy (TEM). Bacterial adhesion to the cell membrane has been extensively reported (5-11). After adhesion, oral epithelial cells may play an important role in host immune response towards infection because the epithelial cell membrane ingrowths to engulf the bacteria forming a phagocytic cup and internalizing the bacteria (12).

This study demonstrates the presence of groups of bacteria adhered to epithelial cell membranes of tongue 
mucosa of young rats using high resolution SEM(HRSEM) and TEM. This fact may play a key role in native flora formation and future bacterial disease prevention.

\section{MATERIAL AND METHODS}

Ten 3-day postnatal Wistar rats were fixed by immersion in modified Karnovsky fixative solution containing $2.5 \%$ glutaraldehyde, $2 \%$ paraformaldehyde in a $0.1 \mathrm{M}(\mathrm{pH} 7.3)$ sodium cacodylate buffer. For HRSEM analysis, the specimens were fixed in the same fixative solution for $12 \mathrm{~h}$ at $4^{\circ} \mathrm{C}$ and were postfixed in $2 \%$ buffered osmium tetroxide solution, rinsed in distilled water for at least $3 \mathrm{~h}$ and immersed in $2 \%$ tannic acid aqueous solution for $1 \mathrm{~h}$ at room temperature. The samples were rinsed in distilled water for $5 \mathrm{~h}$ and postfixed with $2 \%$ osmium tetroxide solution. They were dehydrated in series of ethanol and tert-buthyl alcohol, freeze-dried in Eiko ID-2 apparatus, mounted on a metal lamina and coated with platinum-palladium in a BIO-RAD (SEM Coating System; Microscience Division, Tokyo, Japan). The samples were examined in a HRSE microscope (Hitachi, S-900; Hitachi, Tokyo, Japan).

For TEM analysis, the specimens were fixed in the same solution, postfixed in $1 \%$ osmium tetroxide solution during $12 \mathrm{~h}$ at $4^{\circ} \mathrm{C}$, dehydrated in an increasing series of ethanol and propylene oxide and embedded in Spurr resin, according to Watanabe et al. (13). Thick sections were obtained using glass knives, stained with toluidine blue solution and examined under light microscopy. Ultrathin sections were obtained in a ultramicrotome with a diamond knife (Ultracut Reichert, Vienna, Austria) and collected on 200-mesh grids with Formvar film. Grids were counterstained with uranyl acetate and lead citrate and examined with a TE microscope at $80 \mathrm{kV}$ (1010; JEOL, Tokyo, Japan).

\section{RESULTS}

The samples of 3-day postnatal rat tongue mucosa examined under HRSEM showed the presence of numerous microplicae on epithelial cell membrane surface (Fig. 1A). The shape of the spaces between plicae varied being elongated or circular.

Several groups of bacteria attached to the surface of keratinized epithelium were detected in threedimensional images. Groups of coccus and staphylo- coccus were located in several regions of filiform and fungiform papillae being the coccus distributed at random (Fig. 1B) and staphylococci in rows (Fig. 1C). The staphylococci are attached to the epithelial cell membrane showing the several rows and the small particles in three-dimensional HRSEM images (Fig. C).

TEM images of rat tongue epithelial cell surface revealed numerous bacteria attached to the cell membrane (Figs. 1D and 1E). The fine filamentous structure containing glycocalyx permitted the adhesion of each other and the surface of epithelial cells and the bacteria surface. At high magnification, TEM images revealed the meshwork of fine fibrillar material around of surface of bacteria as noted in Figure 1E.

\section{DISCUSSION}

The results revealed that filiform and fungiform papillae of 3-day postnatal rat tongue mucosa presented numerous microplicae of different forms in threedimensional HRSEM images. The epithelial cell membranes showed microplicae similar to those demonstrated in previous studies $(1,4)$. In addition, the findings of the present study confirm that the rat tongue mucosa epithelial cell surface present bacterial groups attached to cell membranes. These characteristics were also reported by Brady et al. (6), revealing bacteria in the filiform papillae of adult rat tongue mucosa.

In 3-day postnatal rats, attachment of microorganisms was observed only in the outer surface of keratinized epithelial cells. However, Brady et al. (6) emphasized that in adult rats, bacteria penetrates to the 3 rd or 4th epithelial cell layer. Penetration of microorganisms depends on the location and epithelial cell features. Location is important because there are several mechanical conditions that may detach the bacteria, e.g., mastication, salivary flow and breathing. Epithelial cell features are important because they express receptors that are adhesion sites for specific bacterial adhesins. Moreover, the epithelial cell membrane invaginates to engulf the bacteria forming a phagocytic cup and internalizing them (12). It is inferred that more time is required for bacteria to achieve deeper layers in the epithelium.

In this study, rat tongue mucosa presented microorganisms, usually in coccal form, as reported elsewhere (7), or staphylococcus attached to epithelial cell surface. Bacterial characteristics, e.g., being gram positive or gram negative, could not be seen in the SEM study. 

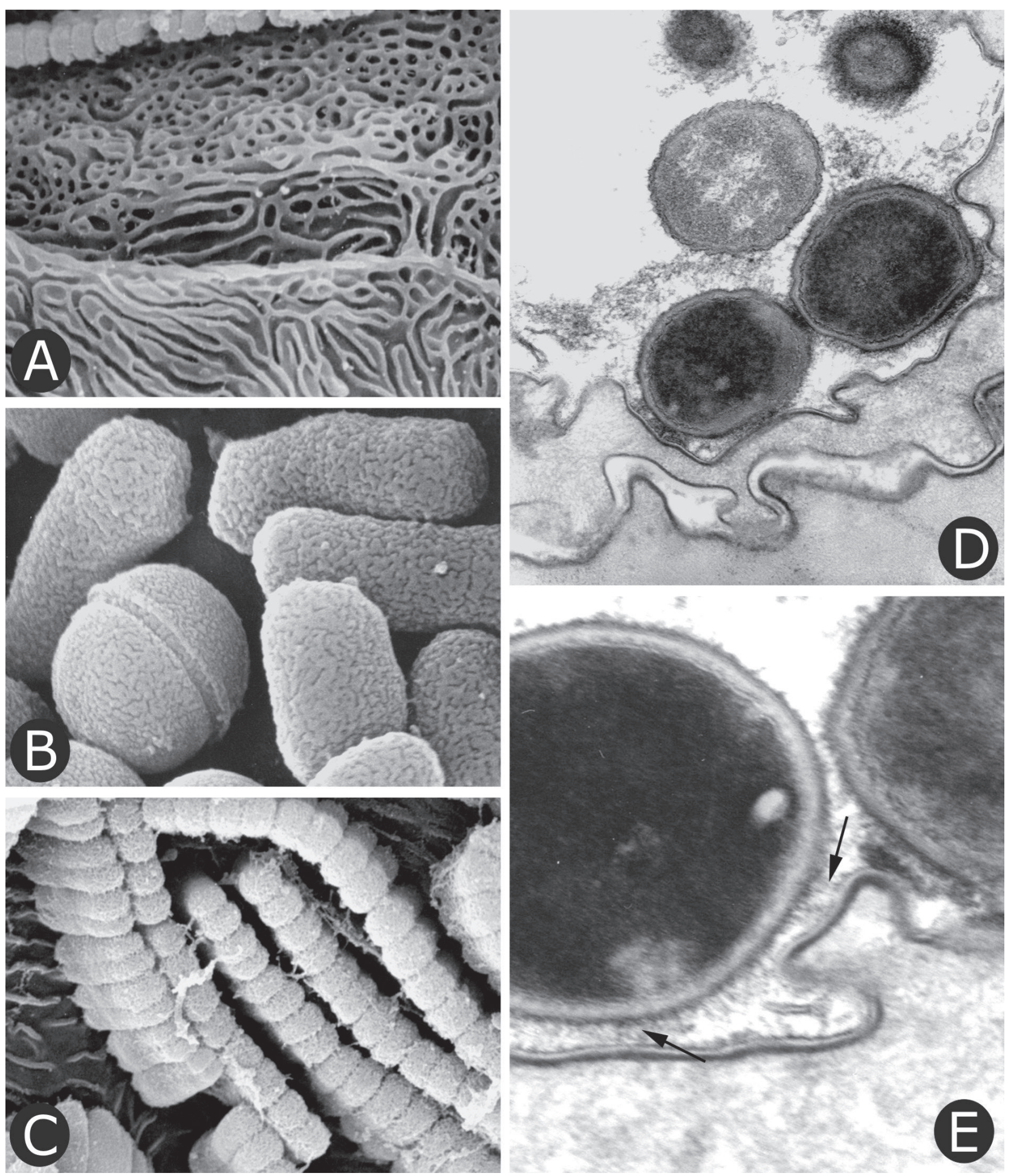

Figure 1. Panel of high resolution scanning electron microscopy (HRSEM) and transmission electron microscopy (TEM) images.
$A=$ HRSEM image of rat filiform papilla surface. The epithelial cell membrane shows numerous microplicae of different forms $(\times 37,000)$; $B=$ HRSEM image of filiform papilla showing numerous bacteria located at random $(\times 60,000)$; $C=\mathrm{HRSEM}$ image of staphylococcus showing the several rows in three-dimensional HRSEM images $(\times 17,000)$; $\mathrm{D}=\mathrm{TEM}$ image of keratinized epithelial cell membranes revealing the adherence of bacteria $(\times 35,000)$; $=$ TEM image of epithelial cell surface. Shows the round bacteria attached by filamentous material (arrows), glicocalix $(\times 56,000)$. 
The process of attachment of microorganisms to epithelial cell surface occurred through an interaction between fibrillar substance and epithelial cell membranes, as demonstrated by the TEM images and by Vitkov (14). However, streptococcal adhesion to cells may occur in the complex structure formed by proteins (5). The results of the present study showed that microorganisms are attached to epithelial cell membranes of the filiform and fungiform papillae through numerous fibrils structure like glycocalyx. Similar findings in rat tongue mucosa have been reported.

Tokunaga et al. (11) and Howlett and Squier (15) have presented ultrastructural findings on Candida albicans adhesion, reporting the mechanisms of interaction between this yeast and epithelium cell surface. However, there are evidences that cell wall is the most important site for Candida adhesion $(10,16)$. Salivary flow rate and salivary neutrophil function have also been described as factors that increase the incidence of Candida in aged people (17).

The outcomes of this study confirmed the existence of a complex network of filamentous materials between bacteria surface and epithelial cell membranes clearly noted by TEM and in three-dimensional HRSEM images. These characteristics are important on the examination of the molecular structure of adhesins and may be used for the future control or prevention of bacterial diseases and for installation of oral native flora.

\section{RESUMO}

A superfície lingual de ratos de três dias de idade foi examinada em microscópia eletrônica de transmissão (MET) e em microscópia eletrônica varredura de alta resolução (MEVAR). Para o método de MEVAR, os espécimes foram fixados na mesma solução por $24 \mathrm{~h}$, pós fixados em solução de tetróxido de ósmio a $2 \%$, secos em ponto crítico e cobertos com platinapaládio. Para análise em MET, os espécimes foram fixados utilizando-se solução de Karnovsky modificada e emblocadas em resina Spurr. Os resultados mostraram a presença de numerosas micropregas na membrana superficial das células epiteliais queratinizadas, nas quais estavam aderidos grupos de bactérias. Estas bactérias eram estafilococos e cocos, organizados em fileiras ou a esmo, e puderam ser observadas em imagens tridimensionais em MEVAR. Em maiores aumentos, as imagens em MET revelaram a adesão de bactérias nas células por meio de numerosas estruturas filamentares compondo o glicocálice. As delicadas estruturas filamentares na periferia das bactérias e das células foram nitidamente identificadas. Estas características da estrutura bacteriana podem ser utilizadas, no futuro, para controle e prevenção de doenças bacteriana, bem como para a instalação da flora oral nativa.

\section{ACKNOWLEDGEMENTS}

This study was supported by CNPq.

\section{REFERENCES}

1. Yoshioka I, Muto H. Surface structure of tongue, palate and buccal mucosa of rat by scanning electron microscopic study. Okaj Folia Anat 1976;52:277-312.

2. Iwasaki S, Yoshizawa H, Kawahara I. Three-dimensional ultrastructure of the surface of the tongue of the rat snake, Elaphe climacophora. Anat Rec 1996;245:9-12.

3. Iwasaki S, Asami T, Wanichanon C. Fine structure of the dorsal lingual epithelium of the juvenile hawksbill turtle, Gretmochelys imbriata bissa. Anat Rec 1996;244:437-443.

4. Silva MC, Watanabe I, Kronka MC. Three-dimensional architecture of the connective tissue core and surface structures of the lingual papillae in the rabbit. Histol Histopathol 2002;17:455-461.

5. Barnett ML. Adherence of bacteria to oral epithelium in vivo: electron microscopic observations. J Dent Res 1973;52:1160.

6. Brady JM, Gray WA, Lara-Garcia W. Localization of bacteria on the rat tongue with scanning and transmission electron microscopy. J Dent Res 1975;54:777-782.

7. Watanabe I, Jin C, Nagata T. Field emission scanning electron microscopic study of the mouse lingual mucosa, with special reference to adhesion of bacteria in the epithelia cell membranes. Braz J Morphol Sci 1997; 14:247-251.

8. Motoyama AA, Watanabe I, Semprini M, Lopes RA, Iyomasa MM, Mizusaki CI. Scanning electron microscopy of the rat tongue mucosa with special attention to the bacteria on epithelial cell membrane. Braz Dent J 1999;10:11-14.

9. Douglas LJ, Houston JG, Mccourtie J. Adherence of Candida albicans to human buccal epithelial cells after growth on different carbon souces. FEMS Microbiol Lett 1981;12:241-243.

10. Mccourtie J, Douglas LJ. Extracellular polymer of Candida albicans isolation, analysis and role in adhesion. J Gen Microbiol 1985;131:495-503.

11. Tokunaga M, Niimi M, Kusamichi M, Koike H. Initial attachment of Candida albicans cells to buccal epithelial cells. Mycopathologia 1990;111:61-66.

12. Vitkov L, Krautgartner WD, Hannig M. Bacterial internalization in periodontitis. Oral Microbiol Immunol 2005;20:317-321.

13. Watanabe I, Jin C, Nagata T. Filed emission SEM, conventional TEM and HVTEM study of submandibular gland in prenatal and postnatal aging mouse. Histol Histopathol 1997;12:447-457.

14. Vitkov L, Krautgartner WD, Hannig M, Fuchs K. Fimbriamediated bacterial adhesion to human oral epithelium. FEMS Microbiology Letters 2001;202:25-30.

15. Howlett JA, Squier CA. Candida albicans: ultrastructure, colonization and invasion of oral epithelium. Infect Immun 1980;29:252-260.

16. Critchley IA, Douglas LJ. Isolation and partial characterization of an adhesion from Candida albicans. J Gen Microbiol 1987;133:629-636.

17. Tanida TT, Ueta E, Tobiume A, Hamada T, Rao F, Osaki T. Influence of aging on candidal growth and adhesion regulatory agents in saliva. J Oral Pathol Med 2001;30:328-335.

Accepted October 2, 2007 